\title{
Informal settlement upgrading and safety: experiences from Cape Town, South Africa
}

\author{
Mercy Brown-Luthango ${ }^{1}$ (D) Elena Reyes $^{1} \cdot$ Mntungwa Gubevu $^{1}$
}

Received: 7 August 2015/Accepted: 19 July 2016/Published online: 27 July 2016

(C) Springer Science+Business Media Dordrecht 2016

\begin{abstract}
Informal settlement dwellers are disproportionately affected by ill health, violence and many other socio-economic challenges. These are largely connected to the unhealthy and unsafe physical conditions within which they live. Interventions in the built form through the provision of physical infrastructure have been proposed as a strategy to improve economic, social and health outcomes for informal settlement dwellers and are also suggested as tools to address violence and insecurity, which have reached unprecedented levels in many cities of the South. Whereas there is a clear case for improving the living conditions of people in slums, there is still much debate and uncertainty about what exactly constitutes upgrading, the most appropriate methods and approaches to upgrading, and what the objectives and desired outcomes of upgrading interventions ought to be. This paper tries to shed light on the complexity of upgrading interventions through a comparison of three upgrading projects, each utilising a particular method and approach, and their impact on the perception of safety of their beneficiaries. The research findings show that physical improvements and a full package of basic services are absolutely crucial to improve the living conditions, reduce vulnerabilities and improve the safety of informal settlement dwellers. But these need to be supported by social and economic programmes in order to bring about tangible improvements in people's life circumstances. Research across the three sites, however, suggests that in a context marked by high unemployment, poor education and limited opportunities to break the cycle of poverty, the long-term impact and sustainability of upgrading interventions is limited in the absence of targeted programmes
\end{abstract}

Mercy Brown-Luthango

mercy.brown-luthango@uct.ac.za

Elena Reyes

elena.reyesb@gmail.com

Mntungwa Gubevu

GBVMNT001@myuct.ac.za

1 African Centre for Cities, School of Architecture, Planning and Geomatics, Room 2.11,

Environmental and Geographical Science Building, Upper Campus, University of Cape Town,

Rondebosch, Cape Town 7701, South Africa 
aimed at addressing the structural factors which drive and sustain high levels of violence and crime.

Keywords Informal settlements · Housing · Upgrading · Violence · Reblocking · Safety

\section{Introduction}

Growing informality has become a prominent feature in many of South Africa's major urban centres. Improving the living conditions of informal settlement dwellers is a pressing concern for international agencies like the World Bank, United Nations (UN) Habitat and national governments alike. In South Africa this concern was expressed in the goal to "eradicate" informal settlements by 2014. Furthermore, increasing levels of violence and violent crime have been linked to fast-paced urbanisation and informality in developing regions (Muggah 2012). The UN Habitat's 2007 Global Report on Human Settlements entitled "Enhancing Urban Safety and Security" argues that "crime and violence are typically more severe in urban areas and are compounded by their rapid growth" $(2007,6)$. This report proposes interventions in the built form through the provision of physical infrastructure as a strategy to improve economic, social and health outcomes for informal settlement dwellers, and as a tool to address growing violence and insecurity, which have reached unprecedented levels in many cities of the South. However, it is argued that upgrading in itself will not have a significant impact in terms of improving the lives of informal dwellers and might in some instances have a negative effect on their livelihoods post upgrading. For instance, case studies from upgrading projects in Latin America, India and Africa seem to suggest that different methods and approaches to upgrading have a bearing on the long-term sustainability of these interventions (Abbott 2002a; Baker 2006; Sheuya 2008; Koster and Nuijten 2012). In terms of violence and insecurity, it is argued that in order for upgrading projects to bring about tangible improvements in the living conditions of the beneficiaries of these projects, upgrading needs to be done in a holistic, integrated and participatory manner (UN Habitat 2007; Bauer 2010). Abbott (2002a, b, 2004) calls for a process of "settlement transformation" in which physical interventions are supported by social and economic programmes to reduce the vulnerability of informal settlement dwellers and improve their quality of life.

The main concern of this paper is to consider whether and how the process of upgrading impact the quality of life of residents of informal settlements after the upgrading project, with a particular focus on the nature and extent of violence and insecurity. This will be done by analysing three upgrading projects, located in different neighbourhoods in the city of Cape Town, each using a specific approach to improving the infrastructure and services for residents living in these neighbourhoods. The first settlement, located in Mitchell's Plain, was upgraded into formal housing using the Enhanced People's Housing Process (EPHP), a process where the beneficiaries actively contribute to the decision-making and construction of the houses. The second, located in Philippi, underwent a reblocking process, a spatial reconfiguration in order for services and infrastructure to be installed. In the third one, Monwabisi Park, located in Khayelitsha, a set of social projects and the improvement of public spaces have been implemented as part of the Violence Prevention through Urban Upgrading (VPUU) programme. The paper analyses this case studies with a focus on three main questions: 
1. How has the upgrading project impacted on residents' perception of their life circumstances post upgrading?

2. How has the upgrading project affected residents' perceptions of safety?

3. How have the perceptions of the nature and extent of violence changed since the settlement was upgraded?

The main argument of this paper is that physical improvements and a full package of basic services are absolutely crucial to improve the living conditions, reduce vulnerabilities and improve the safety of informal settlement dwellers, but these need to be supported by social and economic programmes in order to bring about the settlement transformation which Abbott (2002a, b, 2004) refers to. Research across the three sites suggests that in a context of high unemployment, poor education and limited opportunities to break the cycle of poverty, the impact and sustainability of upgrading interventions alone are limited without targeted longer-term state-driven programmes to address the underlying root causes of violence and crime.

\section{Informality and violence}

Urban violence is a serious development concern, especially in cities in the South where rapid urbanisation, coupled with high rates of poverty and inequality result in very bad living conditions for the majority of residents. Increasing levels of violence and violent crime have been linked to these conditions in urban areas (Bourguignon 1999 cited in Kessides 2005; Muggah 2012). It is argued that "when a large population group in cities is afflicted by malnutrition, impoverishment, social exclusion and discrimination, ill health and poor conditions, as well as restricted access to land and basic infrastructure, increasing levels of criminal violence, lack of safety and general fear in the use of public space are often observed" (Bauer 2010; 4).

Africa is perceived as one of the most violent continents, closely followed by Latin America and the Caribbean. South Africa is one of the most violent countries in the world according to a research report released in 2009. It was ranked fourth out of 60 countries in terms of reported rates of burglary, murder and robberies (Kessides 2005). It has a death rate of 157.8 per 100,000 population, which is considerably higher than the average rate of 139.5 per 100,000 population for the African continent, and nearly double the global average of 86.9 per 100,000 population (Seedat et al. 2009). Interpersonal violence accounts for close to half of the injuries resulting in death in South Africa, which is four and a half times the global proportion (ibid). Seedat et al. (2009) highlight poverty and inequality as the most prominent factors accounting for South Africa's considerable challenge of violent injury. Bad living environments in the form of a growing number of informal settlements represent one of the most visible manifestations of poverty and inequality in South Africa.

At the same time, South Africa has one of the largest subsidised housing programmes in the world. Since 1994 the country has delivered more than 3.8 million housing opportunities. ${ }^{1}$ Despite these efforts, the housing backlog continues to grow; the latest Census figures put South Africa's housing backlog at 1.9 million units (Statistics South Africa 2011). South Africa's housing programme has been plagued by a number of challenges. The quality of the houses provided has often been of a very low standard, resulting in more

\footnotetext{
1 www.dhs.gov.za.
} 
resources having to be spent to rehabilitate bad houses. ${ }^{2}$ Many of the new low-cost housing settlements are located on the periphery of the city, far removed from social services and economic opportunities, which means that they have not significantly improved the quality of life of housing beneficiaries. It has become clear that the current model of one-plot-onehouse is financially and environmentally unsustainable and hugely inefficient. It is also clear that the traditional subsidy-linked housing programme is unable to tackle the challenge of growing informal settlements in South Africa. The South African government's response to informal settlements has hitherto ranged from denial to an eradication obsession to some kind of realisation that there is a need to put a specific policy instrument in place to deal with informal settlements. This has resulted in the establishment of the National Upgrading Support Programme (NUSP) the objective of which is to support the National Department of Human Settlements to implement the Upgrading of Informal Settlement Programme (UISP). ${ }^{3}$ However, according to Misselhorn (2008), the requisite shift in mind set from viewing informal settlements as dirty, chaotic and a blight on the urban landscape to a recognition of the important role which they perform as part of the urban environment has not yet occurred. The next section of the paper will provide a brief overview of the debate around informal settlements in South Africa.

\section{Informal settlements and their role in the urban context}

Drawing on Parnell and Hart's (1999) history of self-help housing in South Africa Marx (2003) argues that informal settlements have been a part of the South African urban context for a long time, dating back to colonial times and that they "have neither emerged by accident nor as an 'anomalous' form of urban development" (2003; 299). He argues that their history and reason for being have to be viewed in relation to wider urban and structural processes of poverty, inequality and inefficient land markets and argues for an approach that focusses on providing support to informal settlements rather than one aimed at "improving" them (ibid). In a similar vein, others have argued that informal settlements are part of the urban fabric and they have a particular history, form and function (Huchzermeyer 2006; Smit 2006a, b; Misselhorn 2008). They often represent the first point of arrival and encounter with the city for rural migrants (Misselhorn 2008). Informal settlement residents locate themselves in particular areas for very specific reasons; some of these include access to services, employment opportunities and/or proximity to family and other social networks (Misselhorn 2008).

Informal settlements are complex in terms of their make-up and the particular set of social relationships which operate within them; they are not homogenous (Smit 2006a, b; Misselhorn 2008). Whereas they are often perceived as disorderly, chaotic, unsafe and illegal (in many cases), their internal layout and organisation are well-conceived, functional and supportive of a diversity of informal processes, rules and values. These "informal" arrangements support a multiplicity of livelihood strategies and enable residents to survive and live under extremely precarious conditions with very little support from the state or other sectors of society (Smit 2006a, b; Nuijten et al. 2012; Massey 2013). Our research has shown that life in informal settlements follows a particular logic and order which might not be apparent to outsiders, but makes perfect sense to those who occupy

\footnotetext{
${ }^{2}$ Africa check: the housing fact sheet. https://africacheck.org/factsheets/factsheet-the-housing-situation-insouth-africa/.

${ }^{3}$ http://www.upgradingsupport.org/content/page/about.
} 
them. Misselhorn argues that this "limited understanding of the actual dynamics within informal settlements, the complex social and survival networks that characterise them and of the significant technical and social challenges in effecting housing and infrastructural development for them" result in inappropriate interventions $(2008,4)$.

Whilst acknowledging the significant role that informal settlements play in the urban context, it is also important not to lose sight of the very insecure, unsafe and unhealthy living conditions which many informal settlement residents are exposed to on a daily basis. According to the World Health Organisation (WHO), living in slums is a major cause of ill health, with health defined as "a state of complete physical, mental and social well-being" (Sheuya 2008, 298). Informal settlement dwellers are also more vulnerable to violence and violent crime as argued by the UN Habitat "excluded from the city's opportunities, physically, politically and economically marginalised, slum dwellers are particularly vulnerable to crime and violence" $(2007,1)$. According to a World Bank (2010) report the relationship between violence and the condition of the built environment, especially as it pertains to informal areas, is expressed in two ways. Firstly, lack of physical infrastructure like bad lighting and inadequate sanitation, for example, provide opportunities for violence and crime. Women living in slums are particularly vulnerable to rape and other physical assaults whilst using communal toilet facilities. Secondly, on a psycho-social level, the marginalisation and exclusion experienced by informal settlement dwellers often manifest in interpersonal violence (ibid).

Improving the living conditions of informal settlement dwellers is a pressing concern for international agencies like the World Bank, UN Habitat, the WHO and national governments alike. Interventions in the built form through the provision of physical infrastructure have been proposed as a strategy to improve economic, social and health outcomes for informal settlement dwellers. Abbott (2002a, b) argues that the objective of upgrading projects should be to reduce the vulnerability and risk for informal settlement dwellers. Whereas there is a clear case for improving the living conditions for people in slums, there is still much debate and uncertainty about what exactly constitutes upgrading, which are the most appropriate methods and approaches to upgrading and what the objectives and desired outcomes of upgrading interventions ought to be. Scholars point to a lack of common vision amongst public officials in particular, about how upgrading interventions should impact on the quality of life of informal settlement dwellers (Abbott 2004; Graham 2006; Huchzermeyer 2006; Smit 2006a, b; Nuitjen et al. 2012).

The case studies presented below will attempt to shed light on some of these very complex questions. They represent different contexts and different approaches to upgrading, which means that care has to be taken in comparison and generalisation. However, they do provide very interesting and important insights into what is still a fairly unexplored area of research in South Africa, i.e. the intersection between violence, safety and different types and/or methods of upgrading interventions in informal areas of the city.

\section{Research methods}

This research used a qualitative research design. In the three settlements, in-depth interviews, group interviews, focus group discussions and community crime mapping were conducted with the residents (see summary of research tools in Table 1). Convenience sample was used, and participants were selected on the basis of their accessibility and willingness to participate in the research. It must be noted that due to this, the sample included mostly unemployed people who were at home during this time of the day. In each 
Table 1 Summary of Case Studies

\begin{tabular}{|c|c|c|c|}
\hline Case study & $\begin{array}{l}\text { Freedom Park, Mitchell's } \\
\text { Plain }\end{array}$ & Sheffield Road, Philippi & $\begin{array}{l}\text { Monwabisi Park, } \\
\text { Khayelitsha }\end{array}$ \\
\hline \multicolumn{4}{|c|}{ Upgrading description } \\
\hline $\begin{array}{l}\text { Upgrading } \\
\text { methodology }\end{array}$ & $\begin{array}{l}\text { Provision of formal housing } \\
\text { (ePHP) }\end{array}$ & Reblocking & $\begin{array}{l}\text { Upgrading of public space } \\
\text { and provision of social } \\
\text { services }\end{array}$ \\
\hline Description & $\begin{array}{l}\text { Government-led process } \\
\text { with active community } \\
\text { involvement. Includes } \\
\text { formal housing, provision } \\
\text { of services and tenure }\end{array}$ & $\begin{array}{l}\text { Reconfiguration of the site } \\
\text { to provide streets, public } \\
\text { space and basic services. } \\
\text { Residents also got } \\
\text { materials to improve their } \\
\text { shelters. Residents } \\
\text { participate in the planning }\end{array}$ & $\begin{array}{l}\text { Set of projects including } \\
\text { improvement of public } \\
\text { spaces, provision of basic } \\
\text { services (electricity so } \\
\text { far), tenure certificates } \\
\text { and social services. Does } \\
\text { not include housing. A } \\
\text { community committee } \\
\text { participates in discussions } \\
\text { of priorities and follows } \\
\text { up on implementation }\end{array}$ \\
\hline Carried out by & $\begin{array}{l}\text { Government of the City of } \\
\text { Cape Town }\end{array}$ & $\begin{array}{l}\text { CORC, ISN, iKhayalami, } \\
\text { and local government }\end{array}$ & $\begin{array}{l}\text { VPUU, local government } \\
\text { and other NGO's }\end{array}$ \\
\hline When & 2001-2009 & 2010-2012 & 2009-ongoing \\
\hline $\begin{array}{l}\text { Total } \\
\text { beneficiaries }\end{array}$ & 493 Households & 140 Households & Varies according to project \\
\hline \multicolumn{4}{|l|}{ Research tools } \\
\hline $\begin{array}{l}\text { In-depth } \\
\text { interviews }\end{array}$ & $\begin{array}{l}100 \text { Residents (incl. } 81 \\
\text { Interviews with residents) } \\
1 \text { Group interview with } \\
\text { members of the } \\
\text { neighbourhood watch } \\
2 \text { Members of SAPS } \\
3 \text { Social and community } \\
\text { development workers } \\
5 \text { Government officials } \\
1 \text { NGO's }\end{array}$ & $\begin{array}{l}62 \text { Residents } \\
3 \text { Members of SAPS } \\
1 \text { Group interview with } \\
\text { community development } \\
\text { and social workers }\end{array}$ & $\begin{array}{l}60 \text { Residents (living nearby } \\
\text { improved public spaces) } \\
14 \text { Residents directly } \\
\text { participating in different } \\
\text { projects } \\
7 \text { VPUU staff members } \\
3 \text { Members of SAPS } \\
4 \text { Partner NGO's } \\
2 \text { Officials from the City of } \\
\text { Cape Town }\end{array}$ \\
\hline $\begin{array}{l}\text { Focus group } \\
\text { discussions }\end{array}$ & $\begin{array}{l}1 \text { Group of } 10 \text { women } \\
\text { between } 18 \text { and } 30 \text { years } \\
\text { old } \\
1 \text { Group of } 12 \text { women above } \\
30 \text { years old }\end{array}$ & $\begin{array}{l}1 \text { Group of } 8 \text { women } \\
18 \text { years old and above } \\
1 \text { Group of } 19 \text { men } 18 \text { years } \\
\text { and older }\end{array}$ & $\begin{array}{l}1 \text { Group of } 6 \text { women } \\
18 \text { years and older } \\
1 \text { Group of } 9 \text { men } 18 \text { years } \\
\text { and older } \\
1 \text { group of } 11 \text { members of } \\
\text { soccer teams }\end{array}$ \\
\hline $\begin{array}{l}\text { Community } \\
\text { crime } \\
\text { mapping }\end{array}$ & 18 Residents & 24 Residents & 11 Residents \\
\hline $\begin{array}{l}\text { Research } \\
\text { carried out }\end{array}$ & 2013 & 2014 & 2014 \\
\hline
\end{tabular}


settlement we worked closely with either the residents committee or another communitybased organisation (CBO) who assisted us in gaining access to research participants. As far as possible, interviews and focus group discussions were conducted in Afrikaans (Freedom Park) and isiXhosa (Sheffield Road and Monwabisi Park); the local languages spoken in the three case study sites.

Community crime mapping was done after the interviews and focus group discussions. It therefore provided a way to triangulate some of the interviews and focus groups data. For this process, it was important to have participants who lived in the settlements before and after it was upgraded. Two enlarged satellite images of the settlements, one from before the upgrading interventions and a second of the upgraded settlement, were provided to the participants and they were asked to indicate the places, times and frequency of incidences of violence and crime.

In addition, other stakeholders were interviewed in order to garner a diversity of voices and perspectives, and to locate the settlements within a broader context. These stakeholders included: members of the South African Police Services (SAPS), social workers and community development workers, officials in the Western Cape Provincial Department of Human Settlements and the Informal Settlement Upgrading Department of the City of Cape Town, and staff members of the VPUU and other partner organizations. Also, due to the variety of projects being implemented in Monwabisi Park, additional interviews were carried out with residents directly participating in specific projects such as the Neighbourhood Watch, Early Childhood Development and the Safe Node Area Committee. An additional focus group with members of the soccer teams was also held for this purpose.

Primary data sources were supplemented with secondary sources like the archives of organisations like the Development Action Group (DAG) (support NGO to the Freedom Park community), the Community Organisation Resource Centre (CORC) (NGO involved in the reblocking process in Sheffield Road) and the VPUU (implementing the upgrading process in Monwabisi Park).

The results from each of the sites were then analysed and compared in relation to the three questions established.

\section{Presenting the cases}

A summary of the methodologies is included in Table 1 above and the location of research sites is included in Fig. 1. A more detailed description of the settlements and the findings is included in the following sections.

\subsection{Freedom Park}

\subsubsection{Background and history}

Freedom Park is located in Mitchell's Plain, the second biggest township in Cape Town. According to the 2011 Census, Mitchell's Plain is part of one of the poorest districts in Cape Town with an unemployment rate of 33.3 and $39 \%$ of the population living in informal dwellings. Mitchell's Plain also experiences high levels of violent crime and is third highest on the list of police districts with regards to the number of reported cases of rape (Gie 2009).

Freedom Park was established in 1998 when a group of backyard dwellers occupied a parcel of vacant land which had been zoned for a school that was never built. The residents 


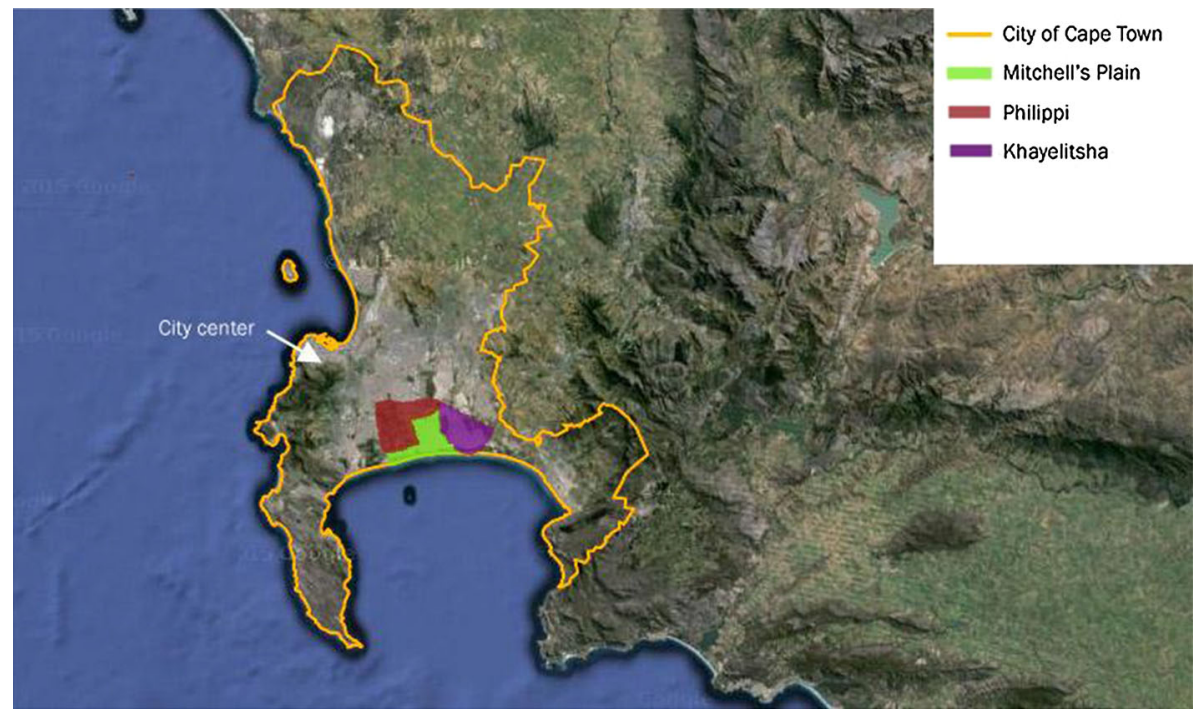

Fig. 1 Location of the settlements in the City of Cape Town

of Freedom Park lived without basic services like water, electricity and sanitation until 2001 when the municipality provided rudimentary services. At the time, four hundred and forty people resided in Freedom Park. A livelihoods analysis conducted by the Development Action Group (DAG) in 2005 revealed crime, drug abuse, alcoholism, domestic violence and community conflict as well as high levels of food insecurity (DAG 2009). Gang violence was a big issue of concern; gang shoot-outs were a regular occurrence as Freedom Park is located in the middle of the territories of two rival gangs fighting for drug turf (DAG 2005; p. 14). Women also faced a constant threat of rape and molestation related to inadequate public lighting in the settlement.

The Freedom Park upgrading was a rollover upgrading which meant that families were not relocated but moved to the boundary of the site, whilst infrastructure was installed. The Freedom Park community was very involved in the upgrading process and participated in the design and layout of the settlement and the layout plan had to go through several iterations before it finally met the approval of the community (Smit 2006a, b; Mah and Rivers 2013). In addition they were also centrally involved in the conceptualisation and choice of house design options. The community identified key priorities for the upgrading with the improvement of safety and security notably first on the list. The construction of formal houses by the government of the City of Cape Town (CoCT) started in 2007 and was completed in 2009. A total of 493 houses were built in Freedom Park; 289 of these were occupied by households residing in Freedom Park and a further 204 houses were provided to families from the City of Cape Town's housing waiting list (DAG 2009).

\subsubsection{Research demographic profile}

The majority of residents who participated in the research were female. Of the 81 respondents, 64 were female, 16 were male and one person did not answer this question. This community faces a number of challenges, with unemployment being a major one. 


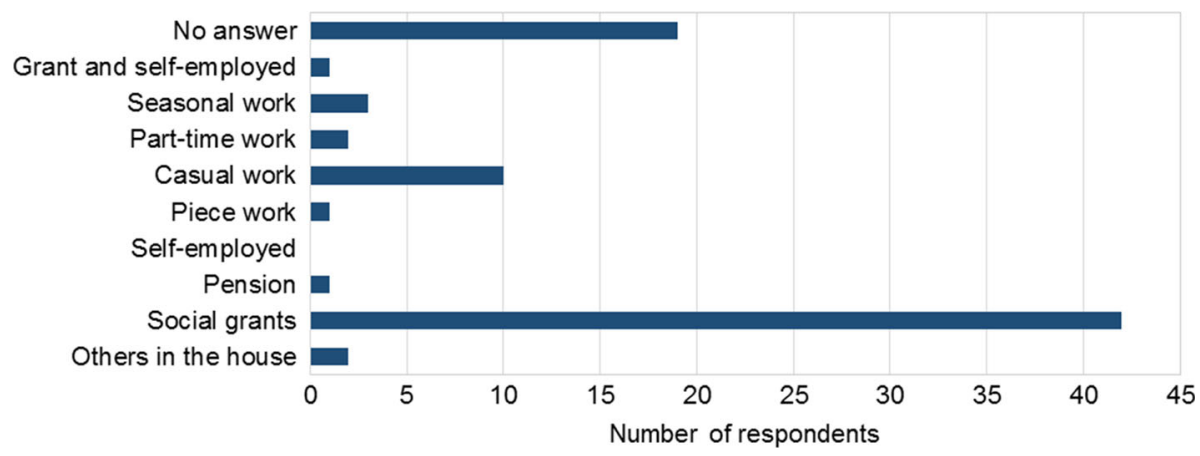

Fig. 2 Means of earning a living for unemployed

Only five of the 81 residents who were interviewed were employed, whereas 72 were unemployed, four did not answer. The unemployed have very limited options in terms of earning a living; with the overwhelming majority of respondents dependent on social grants provided by the State (see Fig. 2).

\subsubsection{Research findings}

a. Life circumstances after upgrading

Respondents had mixed feelings about the impact of the upgrading project on the general quality of their lives. Some felt that the provision of infrastructure and services has made their lives somewhat easier and has given them dignity. This is captured in the quotes below.

We have running water, electricity, flush toilets, dignity has been restored, we can invite people over now, we have walls; we live in houses and not hokkies ${ }^{4}$ anymore

Life was hard in the shacks, we had to get wood to make fire especially in winter, there would be leaking and flooding.

Others felt that the upgrading intervention had not significantly improved their lives; they feel poorer because they now have to pay for services, which they had not expected. This is particularly difficult given high rates of unemployment and a lack of alternative livelihood strategies. An unintended consequence of the project is that there appears to have been a breakdown in community cohesion and neighbourliness following the upgrading project. Some participants relate this to the receipt of the house which they feel is contributing to individualism and a lack of concern for one another's well-being.

I am struggling and feel poorer, if you don't have money, no job, you will have to make the best of the situation, but it's frustrating

People stood with each other, community changed and friendships fell; community, friendliness has changed for worse; we lived together like a family, now there's no unity

b. Perceptions of safety after upgrading

\footnotetext{
${ }^{4}$ Informal structures made of zinc and wood.
} 


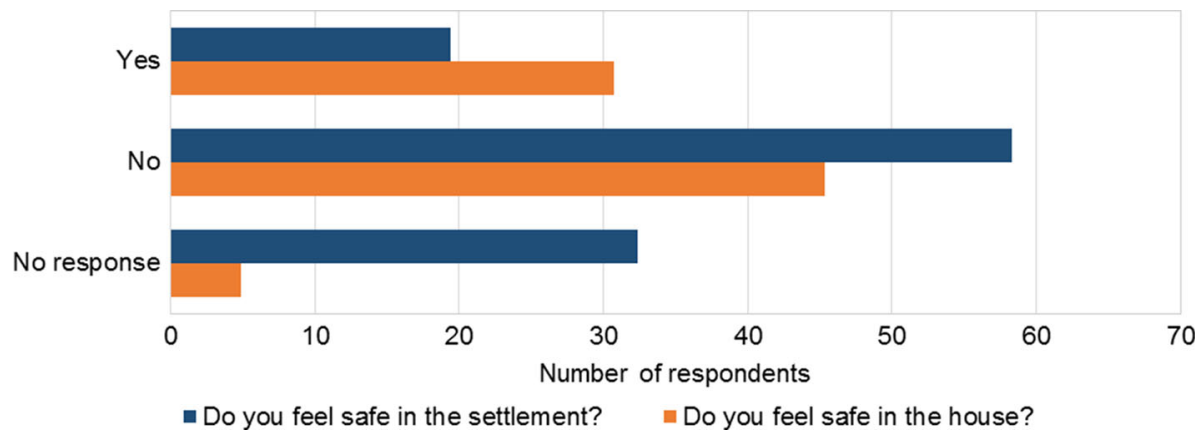

Fig. 3 Perceptions of safety in the settlement and in the house

In terms of respondents' perception of safety the majority of respondents did not feel safe after upgrading (see Fig. 3).

The majority of respondents felt safe in their homes as the house provides refuge from gang violence outside. Respondents felt quite vulnerable in the settlement, and this constrained their mobility and interaction outside the home.

You feel protected with your family in the house; can lock doors properly, create physical and psychological safety; solid structures, bullets can't go through the walls; no gangster can come into my house, but the physical infrastructure of the house does not make me feel safe, the place is very dangerous, you must be in your house always

In cases where people do not feel safe in their house, it is related to the physical quality of the house:

The house is going to collapse anytime, because of the poor building; because they built the houses so cheap; scared the house is going to fall in, leaks and damp

c. Nature and extent of violence after upgrading

Although this community did experience violence and crime whilst living informally, there was a general perception that things had deteriorated since the completion of the upgrading project, with many expressing concern over an increase in gang-related shooting. Types of violence and crime reported to be rife in the settlement include domestic violence and child abuse, whilst there seems to be a decrease in rape and mob justice. The proliferation in the number of informal alcohol and drug outlets since upgrading is reported to have had a substantial impact on the worsening of violence and crime, particularly incidence of fighting in and around these establishments (Fig. 4).

\subsection{Sheffield Road, Philippi}

\subsubsection{Background and history}

Philippi is located close to Cape Town International airport, the Philippi industrial area and the Philippi Horticultural Area. Sheffield Road is an informal settlement situated in the central part of Philippi's area for residential sites near the N2 freeway on a narrow strip of land set aside by the City of Cape Town (CoCT) for the widening of the road called Sheffield Road (CORC 2011; CUFF 2013). The settlement was formed in 1993, when a 


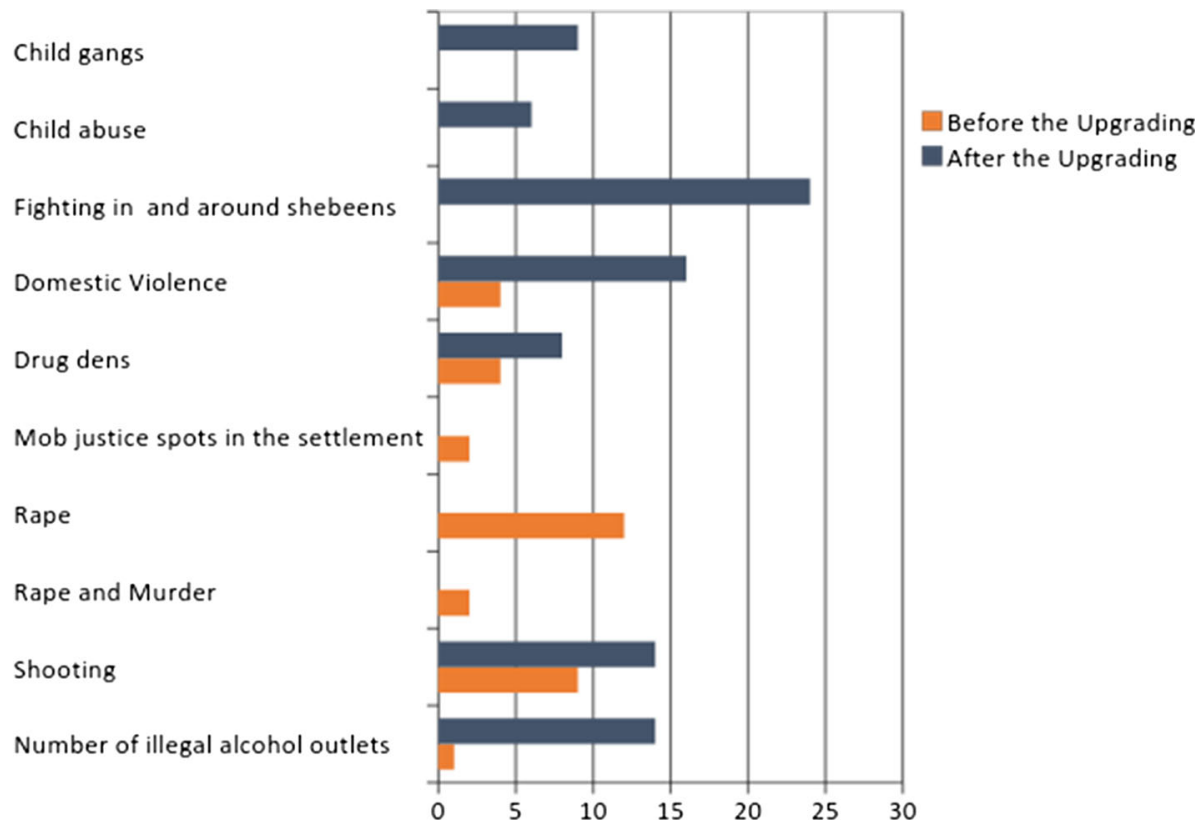

Fig. 4 Perceptions of violence and crime in Freedom Park before and after the upgrading

person erected a shack for an informal business (CORC 2009, 2011). By November 2009 the settlement had 167 families with a total population of 542 people living illegally on the strip of land (CORC 2011; SA SDI Alliance 2013).

The general living conditions in the settlement were poor, especially the shelters and water drainage facilities (CORC 2009). Although the settlement is illegal, as it is situated on state land, the municipal government, CoCT, supplied sanitation services (Ibid). However, in 2009 it was established that with regard to basic services, Sheffield Road had only 15 toilets, and only 7 out of the 15 were functional, and this problem was attributed to vandalism and/or poor drainage (Ibid). This meant that every functional toilet had to be shared by 72 people, and even if all 15 toilets were functional, 33 people would still have to share one toilet. In addition to the sanitation problem, 504 people were serviced by only 3 water taps, meaning that 168 people shared one tap.

The settlement had a history of disasters such as shack fires, flooding and evictions, and there was an urgent need for electricity, water taps and toilets (Ibid). Hence, in 2009 there was an agreement that the CoCT would partner with the Cape Town branch of the Informal Settlement Network (ISN) to identify pilot projects for an incremental approach to upgrading. Sheffield Road was chosen as the first pilot project because its size made the implementation relatively easier (CORC 2009, 2011).

The reblocking ${ }^{5}$ of the settlement started in November 2010 and was completed in February 2012 (CORC 2009; South African Slum Dwellers International (SA SDI)

\footnotetext{
5 'Re-blocking', or 'Blocking-out', is defined as the reconfiguration and repositioning of shelters in very dense informal settlements according to a spatial framework drafted by the community. The aim is to use the spaces in informal settlements better in order to create space for provision of better services by local government. Moreover, re-blocking groups households according to clusters which are identified by the community, and, subsequent to implementation, courtyards are created in order "to ensure a safer
} 
Alliance 2013). Partners that were involved in the project were CORC, ISN, Federation of the Urban Poor (FEDUP), whilst the CoCT was also involved in the installation of engineering infrastructure and in clarifying land management issues (CORC 2011, 2014). Another partner in the project was a technical support NGO called iKhayalami, which specialises "in low cost housing solutions ..." (CORC 2011). Given that reblocking is regarded as an incremental approach to upgrading of human settlements, before the process started, upgrading of Sheffield Road was planned not to focus only on provision of basic services, but to extend to improved shelters, although they would still be informal shelters (CORC 2009). During the reconfiguration of the site, the existing shacks are demolished and replaced with better located and better quality shelters that are more fire resistant, though still informal (SA SDI Alliance 2013). So residents were supplied with fire-resistant materials to rebuild their structures.

\subsubsection{Research demographic profile}

The majority of residents who participated in the research were female. Of the 59 respondents, 34 were female, and 25 were male. Only 22 of the 59 residents who were interviewed were employed full time, whereas 37 were unemployed. The number of unemployed included those who were employed on a contract basis, but considered themselves to be unemployed. The unemployed have a variety of precarious options in terms of earning a living; with the majority of respondents dependent on social grants provided by the State (See Fig. 5).

\subsubsection{Research findings}

\section{a. Life circumstances after upgrading}

A significant majority of those residents who participated in the research feel that their individual and/or families' circumstances became better after the settlement was reblocked, whilst nearly a quarter of the residents, feel that there has not been a difference. Only 5 feel that circumstances became worse, whilst 3 of the respondents said they have "mixed feelings".

Among the people who said their circumstances became better after reblocking, most of them mentioned improvement in the quality of shelters, due to the new, strong metal sheets, which also improve the safety of residents generally. The new materials also improved protection from cold and wet weather conditions and shack fires, as the new ones are stronger. Some of the interviewees also mentioned that the shelters look neat and are bigger and the improved shelter sizes have created space for more privacy. They also welcomed the creation of more space within the settlement, including the improved cleanliness of the environment, hence better protection from health hazards.

Others mentioned increased solidarity in looking after each other's shelters and the idea that people know each other better after reblocking. So besides improvements in the physical infrastructure, including improvements in the layout of the settlement, this group also mentioned increased safety and enhanced community cohesion, as residents came to know each other better after reblocking, and also became more inclined to look after each other's shelters.

Footnote 5 continued

environment ... via neighbourhood watches (all shacks face the courtyard) ... [and] productive places (such as washing lines, food gardens) ..." (SA SDI Alliance 2013, 2015; CoCT 2013). 


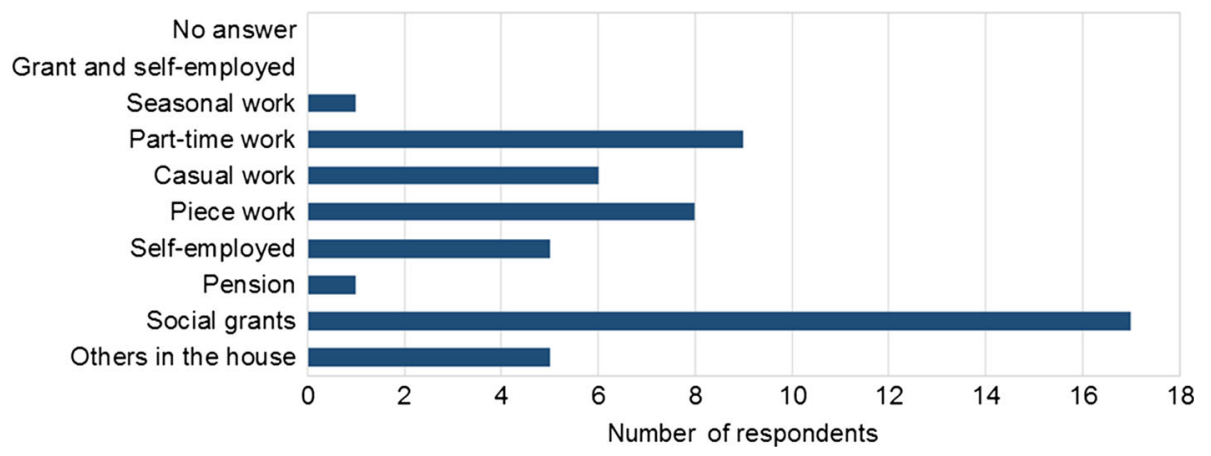

Fig. 5 Means of earning a living for unemployed

Other interviewees mentioned improved sanitation and provision of water, as toilets and water taps had been added. The following quote from one of the residents' interviews captures the way people of Sheffield Road see an improvement in the quality of their lives after reblocking.

"Before re-blocking, the shacks were built with wood, and were congested. The toilets and water taps were not enough. There was also a lot of crime, because if you went to work you would find your shack broken into. What has changed is that since there are spaces that have been created within the settlement after re- blocking, people can see criminals. Relations with local councillors also improved after re-blocking.

Re-blocking has also restored people's dignity ... Re-blocking has also changed people's behaviour, because now people no longer make the drains situated next to the water taps dirty ... because people who do that are fined R200 ... I used to be embarrassed about the settlement ... but now that is no longer the case anymore."

Interviewees who said their circumstances became worse after reblocking mentioned smaller plots and smaller shelter sizes; leaking roofs and flooding; lack of electricity, including abuse by illegal electricity providers. These respondents expressed a desire to be relocated so that they can build houses, whilst one of them mentioned general disappointment about the end product of the whole reblocking process. The problem of electricity supply and the desire to be relocated emanate from the fact that since residents of Sheffield Road illegally occupied the land, there was no formal issuing of security of tenure by the City of Cape Town (CoCT) even though it supplied basic services and agreed to reblocking of the settlement. Residents are therefore not allowed to build houses on the land because it is still officially reserved for road expansion, whilst the small size of the land would not allow building of houses for all families ${ }^{6}$ (CORC 2009).

b. Perceptions of safety after upgrading

The majority of respondents felt that the settlement is safer after reblocking, compared to before (See Fig. 6).

The overwhelming majority who said they feel safe in the neighbourhood mentioned that the community is cooperating well. Others highlighted the fact that the creation of spaces has left criminals with no places to ambush potential victims. Others mentioned that

627 March 2015 telephone conversation with a member of Sheffield Road Residents Committee, $\mathrm{Mr}$ Akhona Tshete. 
the community deals with criminals accordingly. The addition of toilets closer to the shelters has also improved safety and security of residents.

Most of those who said they do not feel safe mentioned fear of being mugged, whilst others mentioned lack of street lighting and lack of safety for children due to the settlement's closeness to a road. Those who did not feel safe in their shelters said the shelters are less safe than brick houses. Other concerns included fear of criminals; shebeens ${ }^{7}$ that do not close and drunken people who misbehave and fight among themselves; flooding and faulty sewage pipes.

\section{c. Nature and extent of violence after upgrading}

Although most of the interviewees felt that the settlement was not safe and it experienced some level of violence and violent crime before reblocking, there was a general perception that things had improved, especially the reduction in housebreaking, muggings and theft. Most respondents, 25 in total, felt there was neither violence nor violent crime after reblocking.

Figure 7 below tells a slightly different story with regards to violence and violent crime though. It can be observed that no public violence was reported in Sheffield Road before the upgrading, including a significant drop in stabbings as well as a drop in mob justice and a decrease in muggings and murders after reblocking. However, armed robberies increased, and there were also new categories of violence and or violent crime reported, with child abuse and domestic violence cases reported. This is based on the crime-mapping exercise conducted with some of the residents. So whereas residents observed a significant drop in violence and crime in the settlement, the nature of violence and violent crime seemed to have changed after reblocking.

\subsection{Monwabisi Park, Khayelitsha}

\subsubsection{Background and history}

Monwabisi Park is an informal settlement located in the boundary of the former township of Khayelitsha and the Wolfgat Nature Reserve. It started with 1000 dwellings in 1996 when people started arriving to the city from the Eastern Cape. By 2013 it had grown to 6318 dwellings with 17,808 people, representing one-tenth of the informal dwellings in Khayelitsha and $3 \%$ of those in the entire city of Cape Town.

The population of Monwabisi Park is predominantly Black African (99\% in 2011) with $91 \%$ speaking isiXhosa as their first language; $52 \%$ are males and $48 \%$ are females (Frith 2012). Unemployment rates are significantly higher than the city average (24\%) but decreased from $51 \%$ in 2001 to $38 \%$ in 2011. One-fifth of the households in Monwabisi Park reported no income, and $84 \%$ are below the poverty line (R3, 200 (approx. 189 EUR) per month in the City of Cape Town).

Dwellings in the settlement are one-storey structures made of a wooden frame and corrugated shingles, with tires filled with sand as foundation. Windows and doors often have metallic protections (burglar bars). Electricity was provided in 2014 to every house, whilst water and sanitation is supplied through shared facilities. In 2009 the ratio was 1 tap per every 42 households (the minimum is 1 per every 25 families) and people had to walk 5 to $10 \mathrm{~min}$ to reach them (SUN Development 2009). By 2013, only $13 \%$ of the dwellings had individual taps (VPUU 2014). The ratio of toilets was 1 per every 23 dwellings in 2009

\footnotetext{
7 Illegal alcohol outlet.
} 


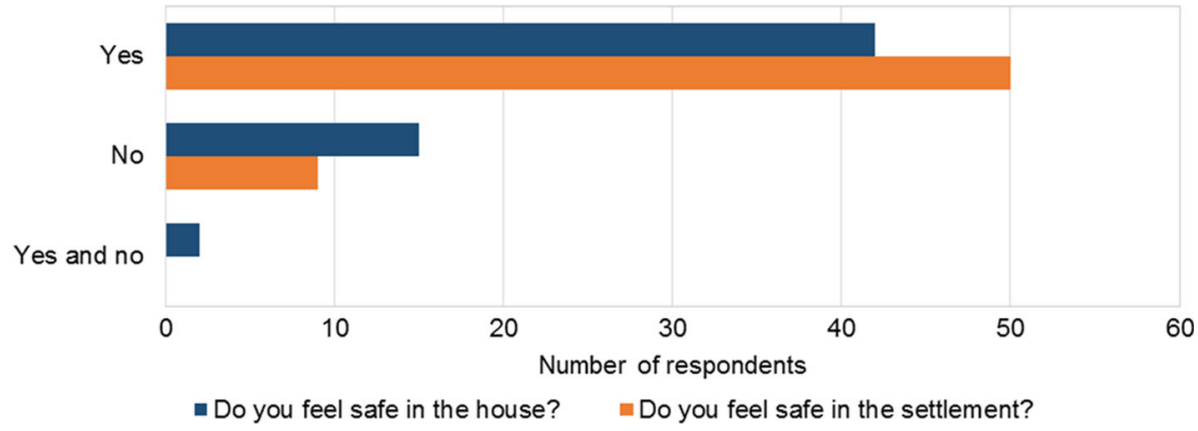

Fig. 6 Perceptions of safety in the settlement and in the house

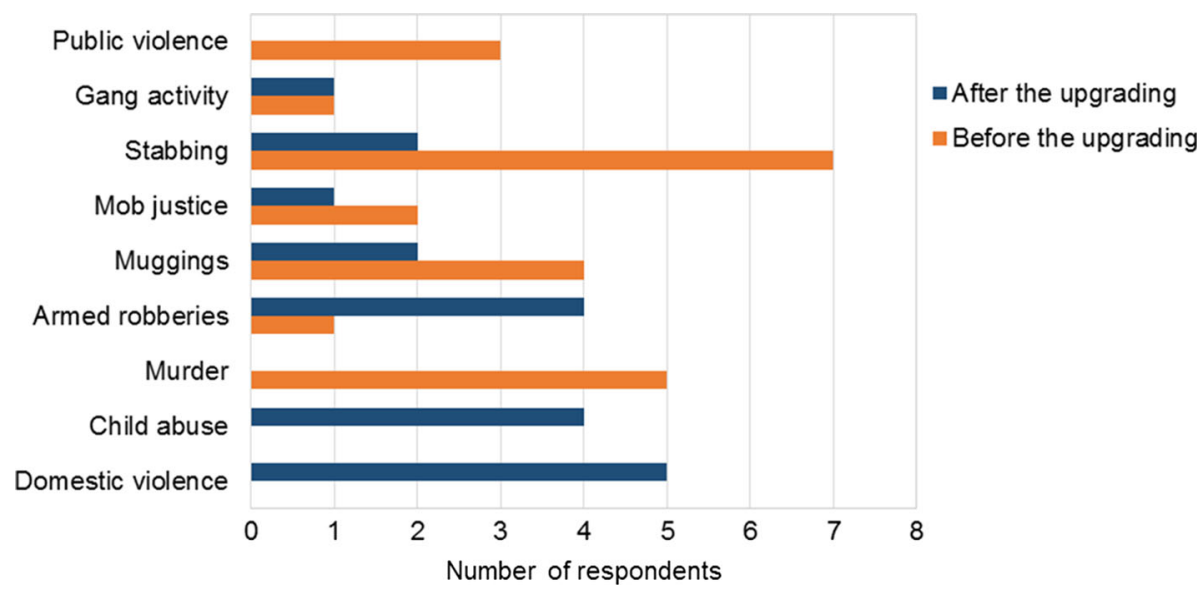

Fig. 7 Perceptions of violence and crime in Sheffield Road before and after the upgrading

(the minimum is 1 per every 5 families), but toilets are often locked or not working. Only $27 \%$ of people said they use them and almost $60 \%$ use the bushes instead (SUN Development 2009).

There are only a few streets since sites are irregular and houses are built very close together, making around $54 \%$ of the settlement inaccessible for emergency vehicles (Jiusto 2008). Flooding is a risk since many of the dwellings are settled below ground level. In 2009 around $58 \%$ reported drainage problems (SUN Development 2009) and in $201350 \%$ of the respondents had experienced flooding during the previous year (VPUU 2014). About $3.5 \%$ of the structures include churches, crèches and small businesses like take away foods, spaza shops and shebeens (VPUU 2014). Also community centre and bed and breakfast was built by the Shaster Foundation in 2005 (WPI 2007) and VPUU constructed a multi-purpose building (Container Facility), two kick-about fields and 7 gathering places along the public taps (Emithonjeni).

Monwabisi Park has long been considered one of the areas with more concentrated crime in the city (Poswa and Levy 2006). The vulnerability to crime and violence-actual and perceived-is linked to the living conditions and high poverty and inequality in the area. It is in this very specific context that the VPUU programme is being implemented. 
The aim of the programme is to prevent violence through a set of interventions (OECD 2010) in a determined geographical area denominated Safe Node Area. The interventions to achieve this strategy include physical upgrading but also other interventions to support human development or the implementation process. So far, the organisation has built in the area a set of small public spaces (Emithonjeni) and several sport fields and a community facility. In addition, several programmes such as a Neighbourhood Watch, Early Childhood Development and a Social Development Fund support sports and cultural activities. In the long term, the almost 40 projects planned for the area include the provision of all basic services, a local economic development strategy as well as other social services.

To implement these interventions, VPUU follows a methodology with five steps: profiling, planning, implementation, operation and maintenance and monitoring and evaluation. This process includes the local government (in this case CoCT) and the community (represented by a local committee-the SNAC), with VPUU as intermediary. Other project partners (local organisations) participate in specific interventions; for example, Sikhula Sonke for ECD and Mosaic Clinic for gender-based violence.

\subsubsection{Research demographic profile}

From the 60 respondents, 31 were women and 29 were men. Similar to the other cases, only 9 of the people interviewed were employed. Others rely mainly on piece work, other members of the house or self-employment (see Fig. 8).

\subsubsection{Research findings}

a. Life circumstances after upgrading

The majority of those interviewed perceived that the settlement is better after the upgrading, but there are still many things that must be improved, such as toilets, streets, houses and the employment situation:

We living okay we have electricity, water close to us. But having only one person working for a family like this. We struggle a lot. We need jobs.

We can have electricity but having to go to the bush to help ourselves, it hurts and we feel that our right is taken away, a right to safety and dignity.

Projects are seen as positive, but issues regarding transparency and communication with VPUU, as well as a mismatch between some of the expectations and the actual scope of the programme have affected the implementation process and the perception of the projects (e.g. the Neighbourhood Watch).

VPUU still has a lot of work to do. Putting electricity we are grateful but what about the rest

VPUU change a lot of thing especially electric but we need road now and houses

b. Perceptions of safety after upgrading

Thirty-five out of the 60 respondents said that in terms of safety, the settlement is better than before. Still, 26 said they did not feel safe in Monwabisi Park and a similar number said that they do not feel safe at home (see Fig. 9). 


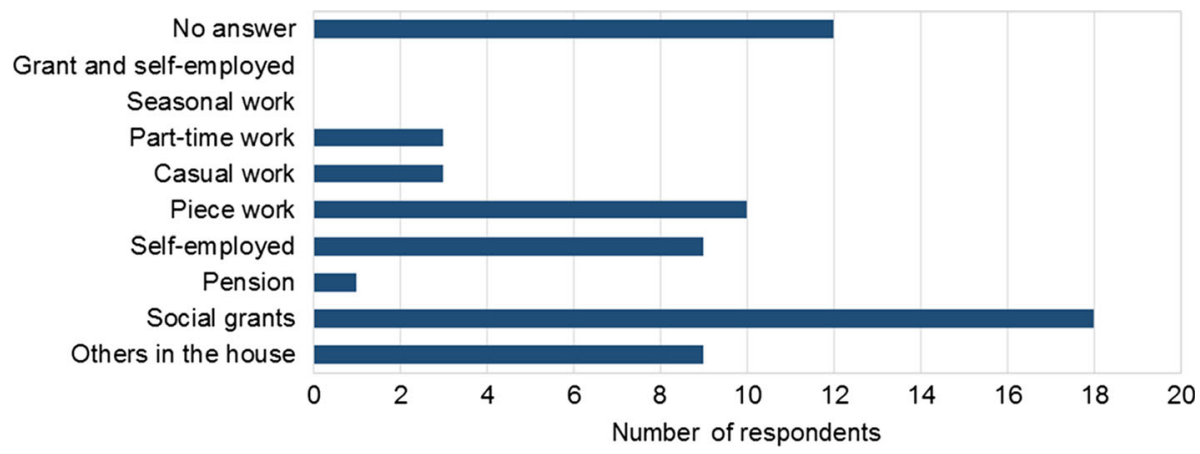

Fig. 8 Means of earning a living for unemployed

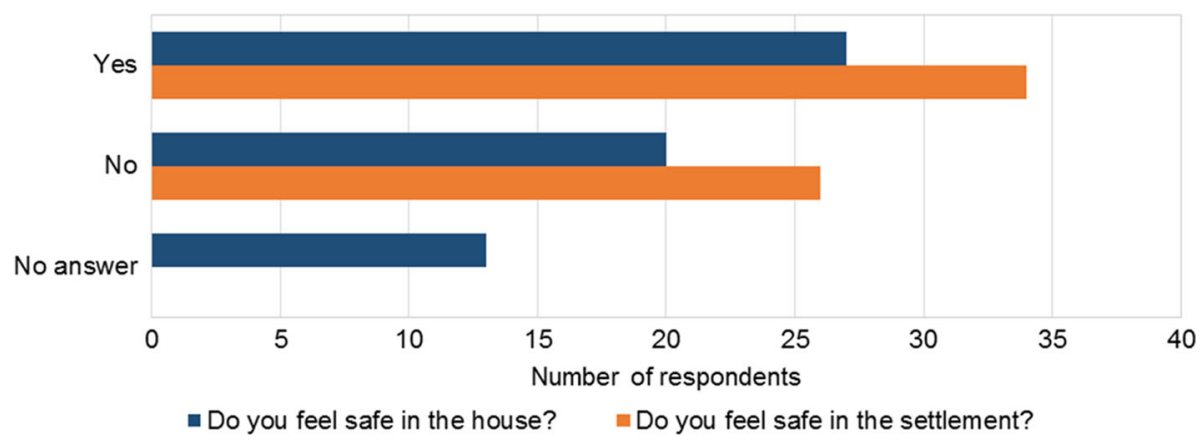

Fig. 9 Perceptions of safety in the settlement and in the house

This could be related to the little or no change in the conditions that make people feel vulnerable to the main crimes suffered (robbery and housebreaking), as one of the respondents mentioned:

We are still in the same informal settlement with leaky shacks and toilets are far and fear hence we use the forest to relieve ourselves

The interviewees participating in specific projects also considered those projects in particular had a positive impact. The main intervention impacting safety is electricity, but other projects such as parks and playgrounds, ECD and sports are perceived to help keep young people and children safer. Residents also perceived a decrease in crime against children (rape and murder) and rape. Safety of children could be linked to the existence of Emithonjenis and to the ECD activities, which provide controlled environments for children's development. The police also mentioned a decrease in mob justice and an improved relationship with the community (who seem more willing to report crime).

The park is near the house so we can see our children when they are playing than to play in the bush. Because they were in the risk of rape

c. Nature and extent of violence after upgrading

The conditions for crime and violence in Monwabisi Park are similar before and after the interventions. Robbery and housebreaking were and are the main concerns and the 


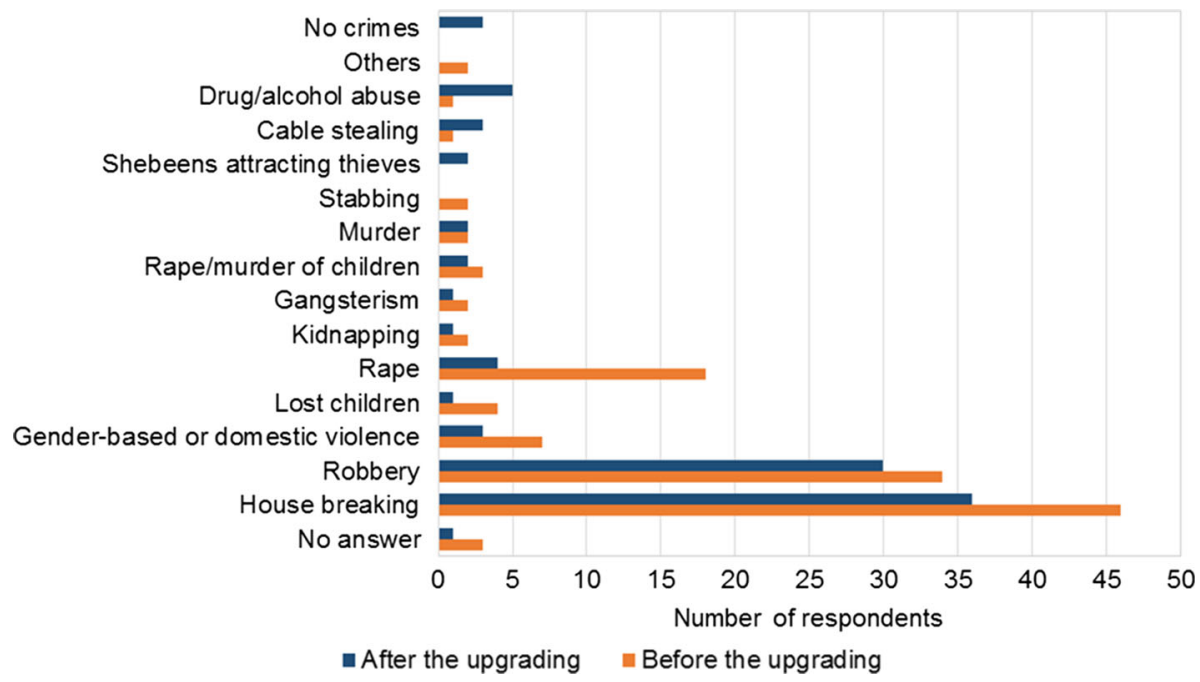

Fig. 10 Perceptions of violence and crime in Monwabisi Park before and after the upgrading

conditions that make people feel vulnerable have not changed. Robbery still occurs in empty fields, on paths on the way to work, or by the bushes, which have to be used because of the lack of toilets. Houses are still temporary structures subject to housebreaking and this means that a great portion of the population feels unsafe even at home. The lack of streets combined with hidden corners and paths between the houses allow criminals to hide whilst impeding police access to the area (Fig. 10).

It should also be mentioned that shebeens are an increasing concern as they are linked to substance abuse and other forms of violence and crime such as fights, rape and gang activity. Copper-cable stealing is also frequent after electrification. And, whilst the community considers patrolling an effective response to crime, it is still closely linked to mob justice.

A challenge for VPUU is that the projects have not met the expectations of the community, since priorities are different: toilets, housing, streets and employment. This becomes especially important since community engagement is expected for the long-term sustainability of the projects.

\section{Discussion of research findings}

First and foremost it must be stressed that the broader socio-spatial context within which these settlements are located are very diverse and the upgrading interventions in each settlement are also quite different. The first settlement is located in a predominantly black Coloured township whilst the other two are located in predominantly black African townships of Philippi and Khayelitsha. Even Philippi and Khayelitsha have different contexts and face different challenges. What is interesting is that although experiences and perceptions of violence, crime and safety vary across the three settlements, there are also important similarities. In Freedom Park, where residents experienced a full upgrading package which included basic services, tenure security and formal housing, the majority of 
respondents expressed dissatisfaction regarding the improvement in quality of life. Here there is great disappointment that the perceived improvement in life which was envisaged to come with a formal house did not materialise. In the other two settlements, residents expressed a greater level of satisfaction with improvement in their quality of life after upgrading. What is very striking though across the three sites, even in Freedom Park, is the impact of the provision of basic services like water, electricity and sanitation. The provision of basic services has a significant impact, both in terms of a physical improvement in people's living conditions as well as the psychological aspects related to feelings of dignity and recognition. This is evident in Monwabisi Park, for example, where the lack of adequate sanitation is causing much distress, despite the investment in the provision of social infrastructure services.

Interesting also, is the fact that in Sheffield Road, the spatial reconfiguration of the dwellings has improved community cohesion and neighbourliness which have contributed to a reduction in violence and crime and increased feelings of safety, although lack of formal electricity supply is also causing much distress and feelings of not being safe. In Freedom Park, quite the opposite happened where respondents felt that the provision of formal houses have contributed to a loss of community cohesion and solidarity amongst residents. This has also had a negative impact on violence and crime in the settlement as informal measures of social control which existed before upgrading and which played a significant role in terms of regulating crime and violence, have all but disappeared. In Monwabisi Park the VPUU methodology is based on a very holistic approach which integrates physical/situational crime prevention, social crime prevention and institutional crime prevention. Although the community and the VPUU came to an agreement about the short-term, medium-term and longer-term interventions for the site, there is frustration amongst the respondents that some of the improvements which they had hoped for have not yet materialised, although the importance of the social crime prevention interventions like the ECD and youth programmes are acknowledged.

A challenge for VPUU is that the projects have not met the expectations of the community, since priorities are different: toilets, housing, streets and employment. In this instance, VPUU and the progress that can be made in the settlement are hampered by the fact that some of the projects are dependent on the city government for implementation. This in some instances has affected community participation, creating despondency and the feeling of failed delivery (even if housing and employment are not part of the interventions). Community participation has also been affected by miscommunication. In the case of the Neighbourhood Watch, some participants felt they were not getting what was expected (a stipend or reward) and some others perceived little feedback was given on their activities. Overall, the community perceived there is little information about the processes outside the community and the way local employment opportunities were allocated. This raises important questions about the role of intermediaries within an upgrading project and difficulty of negotiating and managing multi-partnership interventions.

With regards to perceptions of safety, the research findings from the 3 sites are also quite interesting and point to the multidimensional nature of safety or perceptions of safe spaces. In Freedom Park, the home is perceived as a place of safety, but only insofar as it provides refuge from gang-related violence within the settlement. In Sheffield Road, safety or lack thereof was more linked to concerns over environmental hazards like fire and flooding, rather than violence or crime. In Monwabisi Park, although respondents generally feel safer in the settlement due mainly to the provision of electricity and the improvement of social facilities like the ECD and sports programmes, there is a perception that the broader conditions which contribute to feelings of vulnerability have not been sufficiently 
addressed by the upgrading process. These include the lack of sanitation, streets and pathways in between dwellings to improve accessibility for police and other service vehicles. Another persistent factor contributing to vulnerability is high unemployment which fuels robbery and housebreaking, both of which are still unacceptably prevalent in the settlement. In terms of overall feelings of safety though, respondents from Sheffield Road and Monwabisi Park reported greater levels of satisfaction related to safety after upgrading than did those from Freedom Park. This is surprising because Freedom Park has undergone the full upgrading process, i.e. provision of services, tenure security and a formal house. In Monwabisi Park, where tenure certificates have been provided to all the residents, the VPUU states that this administrative recognition has brought about a significant improvement in perceptions of safety amongst residents.

In terms of the nature and extent of violence after upgrading, in Freedom Park much concern was expressed about a perceived increase in violence, particularly gang-related violence, after upgrading. Other types of violence and crime reported include domestic violence, rape, child neglect, fighting in close proximity to shebeens and house-breaking. This increase in violence and crime was strongly linked to a proliferation in the number of shebeens (informal alcohol outlets) and drug dens. This in turn was blamed on high unemployment and the struggle to cover new expenses like paying for electricity and water which came with the formalisation process. Another contributing factor was the loss of community cohesion and informal social control which occurred subsequent to the upgrading process.

In the Sheffield Road settlement, there seems to be a general perception that the levels of violence and crime have reduced, although different types of violence and crime are reported after upgrading, e.g. domestic violence and child abuse. The improvement in violence and crime were ascribed to the physical improvements which have occurred, i.e. provision of open pathways and spaces between dwellings. This, as well as toilets closer to the dwellings, has limited opportunities for criminals to ambush residents and improved the safety of women and children outside the home. The new cluster arrangement of dwellings has improved neighbourliness and informal surveillance. Respondents also reported that they have a level of control over and measures to deal with potential acts of violence and crime.

In Monwabisi Park although a reduction in violence and crime was reported, due mainly to the provision of electricity and social infrastructure, there was a feeling that the upgrading process has not as yet addressed the conditions which contribute to residents' risk and vulnerability. The lack of toilets means that residents are forced to use the nearby bushes, which put women and children in particular at risk. The physical layout and density of the site makes residents vulnerable to robbery and also hampers patrols by the police. As in the Freedom Park case, increasing concern over shebeens was expressed by both residents and the police as these are seen to add to fighting, rape and gang activity. High unemployment and a need to secure some form of livelihood are contributing factors.

\section{Conclusions}

The findings of this research support the arguments made in the literature about the important role that informal settlements play in the urban context. They provide a housing solution to poor urban residents and the intricate social networks which exist within informal settlements support a range of livelihood strategies. Often informal governance 
structures exist within the settlement; these serve to regulate unacceptable practises which contribute to violence and crime as observed in all three cases. In some instances upgrading interventions might have unintentional consequences, for example, the loss of community cohesion and making people, who are already living precariously, feel poorer as is the case in Freedom Park. Upgrading programmes should take due cognisance of social networks and community cohesion within settlements and should find ways to support and enhance these. Given this, the research supports an in situ upgrading approach that focus on improving the safety, health and well-being of residents, where they are located, through the provision of a comprehensive package of services and infrastructure. Care has to be taken to ensure that upgrading interventions do not disrupt the social support networks and informal measures of social control which perform a vital function in informal settlements.

Another point raised in the literature and confirmed by this research is that a one-sizefits-all approach to informal settlement upgrading is not advisable. This is because the context is markedly different across informal areas and certain upgrading approaches, e.g. reblocking might be more appropriate in certain contexts than others. This confirms the need for a thorough analysis and understanding of the socio-economic and governance context within informal settlements prior to implementing an upgrading intervention and designing interventions accordingly. Community participation and active involvement in the upgrading project is essential, but as the Freedom Park and Monwabisi Park cases show, very difficult to maintain throughout and after completion of the project, especially when the outcomes do not live up to residents' expectations.

A full package of basic services including electricity, water, sufficient and well-maintained sanitation facilities as well as improvements in the physical layout of sites, pathways and public spaces go a long way towards enhancing the general health and well-being of informal settlement dwellers. They also improve perceptions of safety and reduce opportunities for violence and crime. Physical improvements in the built environment are of absolute importance. However, without accompanying social and economic programmes, they will not bring about the "settlement transformation" which Abbott refers to. Even then, the impacts of interventions like upgrading will be minimal and unsustainable in the long run without broader structural change. This is because violence is multifaceted in its manifestations and the factors which drive and sustain it. The research suggests that certain factors can be addressed through an upgrading intervention, whereas structural dimensions need longer-term, targeted, multi-agency programmes to address the root factors which cause and sustain violence and crime.

Upgrading and the provision of shelter should be a component of a much wider strategy to eradicate poverty and inequality by addressing structural conditions like unemployment and a lack of appropriate skill development programmes which contribute to substance abuse as well as interpersonal and community-based violence. It should also be considered that urban upgrading, when accompanied by strategies for economic and social development, become much more complex programmes, which need a long-term scope for their implementation and to observe the results and impacts.

\section{References}

Abbott, J. (2002a). An analysis of informal settlement upgrading and critique of existing methodological approaches. Habitat International, 26, 303-315. 
Abbott, J. (2002b). A Method-based framework for informal settlement upgrading. Habitat International, $26,317-333$.

Abbott, J. (2004). Upgrading an informal settlement in Cape Town, South Africa. In K. Hansen \& M. Vaa (Eds.), Reconsidering Informality: Perspectives from Urban Africa. Spain: Nordika Afrikainstitutet.

Baker, J. L. (2006). Integrated urban upgrading for the poor: The experiences of Ribeira Azul, Salvador, Brazil", World Bank Policy Research Working Paper 3861, March 2006.

Bauer, B. (2010). Violence prevention through urban upgrading: Experience from financial cooperation Germany. German Federal Ministry for Economic Cooperation and Development (BMZ). Frankfurt: Government Printer.

CoCT. (2013). City's plan to overhaul Cape Town's Informal Settlements gets the go-ahead. http://www. capetown.gov.za/en/Pages/CityplantooverhaulCTinformalsettlementsahead.aspx.

Community Organisation Resource Centre (CORC). (2009). Sheffield Road Household Enumeration Report. Cape Town: CORC.

CORC. (2011). The upgrading of Sheffield Road. http://sasdialliance.org.za/wp-content/uploads/docs/ publications/The $\% 20$ Upgrading\%20of\%20Sheffield\%20Road.pdf.

Community Organisation Resource Centre (CORC). (2014). Background to Sheffield Road Household Enumeration Report and Objectives and meaning of the activity. Cape Town: CORC.

Community Upgrading Finance Facility (CUFF). (2013). Masikhase Project Report, Chapter 2, Re-blocking as in-situ upgrading, 13 (30 October 2013).

Development Action Group. (2005). Tafelsig Report. South Africa: Development Action Group.

Development Action Group. (2009). A place to be free: A case study of the Freedom Park informal settlement. South Africa: Development Action Group.

Frith, A. (2012). Census 2011. http://census2011.adrianfrith.com/.

Gie, J. (2009). Crime in Cape Town 2001-2008-A brief analysis of reported violent, property and drugrelated Crime in Cape Town. Cape Town: Strategic Development Information and GIS Department.

Graham, N. (2006). Informal settlement upgrading in Cape Town: challenges, constraints and contradictions within local government. In M. Huchzermeyer \& A. Karam (Eds.), Informal settlements-a perpetual challenge?. Cape Town: UCT Press.

Huchzermeyer, M. (2006). The struggle for in situ upgrading of informal settlement: Case studies from Gauteng. In Paper presented at the Southern African Housing Foundation Conference and Exhibition, Cape Sun, Cape Town.

Jiusto, S. (2008). Envisioning endlovini: Options for redevelopment in Monwabisi Park, Cape Town, South Africa, University's Interactive Qualifying Project. Cape Town: WPI Cape Town Project Centre.

Kessides, C. (2005). The urban transition in Sub-Saharan Africa: Implications for economic growth and poverty reduction, Africa Region, Working Paper Series No. 97.

Koster, M., \& Nuijten, M. (2012). From preamble to post-project frustrations: The shaping of a slum upgrading project in Recife, Brazil. Antipode, 44, 175-196.

Mah, K. W., \& Rivers, P. L. (2013). Negotiating difference in post-apartheid housing design. African Identities,. doi:10.1080/14725843.2013828996.

Marx, C. (2003). Supporting informal settlements. In F. Khan \& P. Thring (Eds.), Housing policy and practice in post-Apartheid South Africa. Sandown: Heinemann Publishers (Pty) Ltd.

Massey, R. (2013). Competing rationalities and informal settlement upgrading in Cape Town, South Africa-a recipe for failure. Journal for Housing and the Built Environment, 28, 605-613.

Misselhorn, M. (2008). Position paper on informal settlement upgrading, part of a strategy for the office of the South African presidency. South Africa: Urban LandMark.

Muggah, R. (2012). Researching the urban dilemma: Urbanisation, poverty and violence. Canada: International Development Research Centre (IDRC).

Nuijten, M., et al. (2012). Regimes of spatial ordering in Brazil: Neoliberalism, leftist populism and modernist aesthetics in slum upgrading in recife. Singapore Journal of Tropical Geography, 33, $157-170$.

OECD. (2010). Violence prevention and empowerment in the township of Khayelitsha, South Africa. Stories of empowerment, OECD better policies for better life. http://www.oecd.org/dac/povertyreduction/ 48869536.pdf.

Parnell, S., \& Hart, D. (1999). Self-help Housing as a flexible instrument of state control in 20th century South Africa. Housing Studies, 14(3), 367-386.

Poswa, N., \& Rasmus, L. (2006). Migration Study in Monwabisi Park (Endlovini), Khayelitsha. Cape Town: Strategic Development Information and GIS Department.

SA SDI Alliance. (2013). CUFF Project Report: Masikhase, Chapter 2. Retrieved March 12, 2014, from http://sasdialliance.org.za/cuff-project-report-2013/. 
SA SDI Alliance. (2015). City of Cape Town adopts re-blocking policy, What is re-blocking all about?. Retrieved March 16, 2015, from http://sasdialliance.org.za/city-of-cape-town-adopts-reblockingpolicy/.

Seedat, M., et al. (2009). Violence and injuries in South Africa: Prioritising an agenda for prevention. Lancet, 374, 1011-1022.

Sheuya, S. A. (2008). Improving the health and lives of people living in slums. Annals of the New York Academy of Science, 1136, 298-306.

Smit, W. (2006a). International trends and good practices in housing: Lessons for South African housing policy. Cape Town: Development Action Group.

Smit, W. (2006b). Understanding the complexities of informal settlements: Insights from Cape Town. In M. Huchzermeyer \& A. Karam (Eds.), Informal settlements - a perpetual challenge?. Cape Town: UCT Press.

Statistics South Africa. (2011). Census 2011 statistical release. South Africa: Statistics South Africa.

SUN Development. (2009). Monwabisi Park in-situ upgrade-baseline survey, internal report. Cape Town: SUN Development.

Un Habitat. (2007). Reducing urban crime and violence: Policy directions-enhancing urban safety and security, Global Report on Human Settlements 2007, (Abridged Ed., Vol. 1). United Nations Human Settlements Programme. London: Earthscan.

VPUU. (2014). Monwabisi Park enumeration-key findings, internal report. Cape Town: VPUU.

World Bank. (2010). Violence in the City-Understanding and Supporting Community responses to urban violence. Washington, DC: The International Bank for Reconstruction and Development/The World Bank.

WPI. (2007). Informal settlement upgrading program, Indlovu Project Report. Worcester: Polytechnic Institute. 